\title{
Craniofacial Biology and Craniofacial Surgery
}


This page intentionally left blank 


\section{Craniofacial Biology and Craniofacial Surgery}
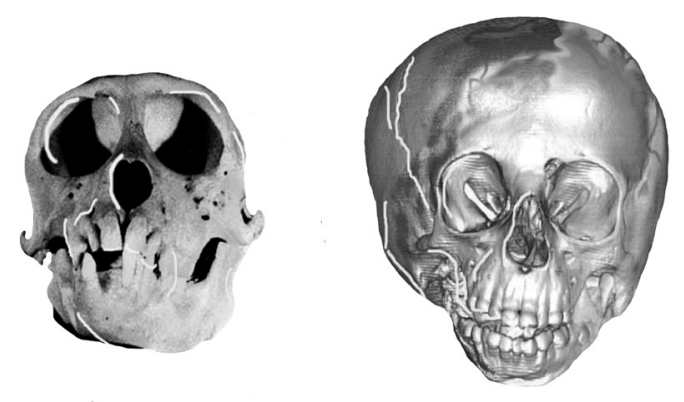

\section{Bernard G Sarnat \& James P Bradley}

University of California

Los Angeles, USA 


\title{
Published by
}

World Scientific Publishing Co. Pte. Ltd.

5 Toh Tuck Link, Singapore 596224

USA office: 27 Warren Street, Suite 401-402, Hackensack, NJ 07601

UK office: 57 Shelton Street, Covent Garden, London WC2H 9HE

\author{
Library of Congress Cataloging-in-Publication Data \\ Sarnat, Bernard G. (Bernard George), 1912- \\ Craniofacial biology and craniofacial surgery / Bernard G. Sarnat, James P Bradley. \\ p. ; cm. \\ Includes bibliographical references and index. \\ ISBN-13: 978-981-283-928-2 (hardcover : alk. paper) \\ ISBN-10: 981-283-928-3 (hardcover : alk. paper) \\ 1. Head--Growth. 2. Face--Growth. 3. Head--Surgery. 4. Face--Surgery. \\ I. Bradley, James P., 1965- II. Title. \\ [DNLM: 1. Craniofacial Abnormalities--surgery--Collected Works. 2. Facial Bones--surgery-- \\ Collected Works. 3. Skull--surgery--Collected Works. WE 705 S246e 2009] \\ QM535.S18 2009 \\ 617.5'1059--dc22
}

2009027540

\section{British Library Cataloguing-in-Publication Data}

A catalogue record for this book is available from the British Library.

Copyright (C) 2010 by World Scientific Publishing Co. Pte. Ltd.

All rights reserved. This book, or parts thereof, may not be reproduced in any form or by any means, electronic or mechanical, including photocopying, recording or any information storage and retrieval system now known or to be invented, without written permission from the Publisher.

\section{Disclaimer}

Many written permissions have been received for use of previously published material. It is a regret that a few written permissions have not been obtained after several repeated requests.

For photocopying of material in this volume, please pay a copying fee through the Copyright Clearance Center, Inc., 222 Rosewood Drive, Danvers, MA 01923, USA. In this case permission to photocopy is not required from the publisher.

Typeset by Stallion Press

Email: enquiries@stallionpress.com

Printed in Singapore. 


\section{Recognition}

To the mentors of Bernard G. Sarnat, M.D., D.D.S.

To the mentors of James P. Bradley, M.D.

\section{Recognition}

To the mentors of Bernard G. Sarnat, M.D., D.D.S., to whom I owe so much:

For research: Isaac Schour, D.D.S, Ph.D.

For general surgery: Marshall Davison, M.D.

For plastic and reconstructive surgery: Vilray P. Blair, M.D., and

Louis T. Byars, M.D.

To the mentors of James P. Bradley, M.D., to whom I owe so much:

For plastic and reconstructive surgery: Joseph G. McCarthy, M.D.

For craniofacial surgery: Henry K. Kawamoto, M.D., D.D.S.

For research: Michael T. Longaker, M.D.

For craniofacial biology: Bernard G. Sarnat, M.D., D.D.S. 
This page intentionally left blank 


\title{
Foreword
}

\author{
"Learning doth make the minds of men gentle, whereas ignorance makes \\ them churlish."
}

Sir Francis Bacon, 1605

The diverse compilation of pre-molecular biological surgical experimentation with advanced stem cell regenerative medicine devoted to the craniofacial complex makes this a unique book. This work combines an historical record of the past with current and future aspirations of diagnosis, prognosis, treatment and prevention of disparities of development. Anomalies of craniofacial development are associated with one third of all congenital birth defects. Whereas most parts of the body are generally concealed below the surface, either by skin or modestly by clothing, the craniofacial complex is the most exposed region of the body, making its defects not only functionally significant, but also having a huge sociological and psychological impact.

Molecular biology and stem cell therapy have revolutionized the study of development and the therapeutic potential of regenerative healing of defects. Rapid advances in our understanding of genetic, molecular and cellular mechanisms underlying craniofacial development are now being translated into novel approaches for disease prevention, tissue repair and regeneration.

Bernie Sarnat's pioneering experiments recorded in this book opened up the possibilities of understanding and modifying the developmental 
distortions that current genetic and molecular biological expositions are revealing as the root causes. His co-author, James Bradley, has taken advantage of this tremendous biological background to implement therapeutic and surgical procedures to alleviate disabilities and deformations by employing the technologies of diagnostic capabilities rendered by radiology, CAT-scanning, MRI imaging, ultrasonography and ultimately genetically-based prognoses.

The variations of the components of the oro-gnatho-masticatory apparatus, both in their normal and abnormal development, whether of greater or lesser clinical significance, are manifestations of an assuredly genetical underpinning. Furthermore, epigenetic influences on gene expression patterns are being revealed in phenotypic portrayals of genetic inheritance, that, if defective, have been modified by Bernie Sarnat's experiments and James Bradley's surgical skills.

The initially relatively less complex experiments performed in the early mid-20th century by Bernie Sarnat have given way in the 21st century to insights being revealed by the more sophisticated experiments by the refinements of genetic microarray analyses, tissue culture technology, regenerative medicine, organ transplantation, laser lysing of tissues and robotically-controlled surgery in the hands of James Bradley. Bernie Sarnat's innovative experiments on bone biology that have been published over an astonishing 70 year period from 1940 to the present book in 2010 have been cited over 117 times in the research engine "Scopus", attesting to his enormous impact on craniofacial biological research. His work has provided the necessary infrastructural background that has allowed James Bradley to undertake the heroic surgical reconstructions described in this book. The combination of the seminal works of a pioneering biologist with those of a practicing plastic surgeon represented in this book provides a phenomenal insight into overcoming the traditional barriers between laboratory science and clinical practice that the two authors of this book have displayed.

To these variegated musings on the combination of basic sciences with surgical expertise exemplified in this book, the reader has a potential Lucullan feast of thought upon which to chew. As Sir Francis Bacon 
observed: "Some books are to be tasted, others to be swallowed, and some few to be chewed and digested". Enjoy the contents of this book.

Geoffrey H. Sperber, B.Sc. (Hon), B.D.S., Ph.D. Professor Emeritus Faculty of Medicine \& Dentistry 6074 Dent/Pharm Centre University of Alberta Edmonton, $\mathrm{AB}$ T6G 2N8 Canada 
This page intentionally left blank 


\section{Foreword}

Bernard G. Sarnat was the John Hunter of 20th century plastic surgery. Like the celebrated 18th century English surgeon, considered the father of surgical research, Sarnat had an unquenchable curiosity based on observations made during his daily clinical activities. Ever logical, he then went to the animal laboratory to seek the answers.

After obtaining medical and dental degrees, he took his surgical training at the St. Louis shrine of plastic surgery led by Dr. Vilray Blair, recognized as the Father of American Plastic Surgery. This educational background, combined with his personal temperament, set the stage or provided the foundation for a lifetime of asking pertinent clinical questions regarding the growth of the craniofacial skeleton: How can one study the growth of the mandible, midface, orbits and cranial vault? Does the normal craniofacial skeleton grow differently than the abnormal? Does an abnormality in one component of the craniofacial skeleton set off a "domino effect" in contiguous structures? Are the individual roles of the bones, cartilage, teeth and soft tissue envelope integrated to achieve final craniofacial skeletal morphology? How does one produce phenocopies of pathologic craniofacial human conditions? Sarnat realized that these questions could be answered only in the laboratory.

It is remarkable how many animal models he developed - turtles, rats, gophers, lagomorphs, pigs, dogs, and primates. To answer these questions, he recognized that experiments must include craniofacially immature as well as mature animals. One then has to ask the question 
whether these experimental findings were transferable to the human. For example, the rabbit can be a "bone factory"; the canine is predominantly a snout animal; only the primates have the circumferential orbit of the human.

Yet, Bernard G. Sarnat was not to be deterred. Over a career that spanned the last half of the 20th century, he studied the role of the condyle and the effect of neuromuscular function on mandibular growth; the contribution of the nasal bones, septum and paranasal sinuses and facial sutures in rabbit and primate midface development; the effect of globe enlargement in orbital development; and the role of the cranial and skull base sutures in cranial vault development.

His experimental designs were ever simple and intuitive - local surgical manipulation. It was only natural that, as a surgeon, he used the tools of his trade in an investigative manner - not unlike John Hunter's transplant experiment with combs of cocks.

What resulted was an improved understanding of craniofacial growth and development - the interplay of functional parts determining skeletal growth. An excellent example is the development of the forehead in response to frontal lobe emergence in higher animals. From an evolutionary standpoint, higher animals needed a second story addition. As humans assumed the upright position, olfaction became less important and snout size decreased (and the hands became more complex!). The frontal bone and the enlarged cranial vault represent the skeletal addition for the everevolving cerebral cortex.

In many ways, Bernard G. Sarnat's work set the stage for my generation of craniofacial surgeons. The distraction technique could be employed in the young patient with recognition that the severely hypoplastic mandible had little potential for growth and development. As surgeons, we learned that the midface in syndromic craniofacial synostosis, likewise, had little potential for growth. Consequently, the Le Fort III advancement technique could be employed in these patients at a young age to improve occlusion, relieve sleep apnea and restore facial aesthetics and the surgeon would not be interfering with midface growth.

And now this remarkable surgeon, in the ninth decade of his life, is working with an academic surgeon, who is two surgical generations 
younger, in bringing this remarkable tale of research to print and to relate it to modern craniofacial surgery and to contemporary research in this area - it is truly a story of our specialty over 60 years. What a contribution to the discipline of craniofacial surgery by two surgeons whose work transcends two centuries of work!

Joseph G. McCarthy, M.D. Lawrence P. Bell Professor of Plastic Surgery Director, The Institute of Reconstructive Plastic Surgery New York University Langone Medical Center 550 First Avenue New York, NY 10016 
This page intentionally left blank 


\section{Preface}

This is an unusual one of a kind work. Something old. Something new which is based in part on something old.

It deals primarily with and brings together a wide ranging group of essays many of which are classics of more than half a century of research done by the senior author. Much of this historical review remains significant and germane today. Some material antedates the emergence of the specialties of craniofacial biology, craniofacial surgery and bone biology. Many of the reports preceded the period of molecular biology. This summary represents a fundamental pioneering contribution to a representative portion of the specialties. A diverse group of experiments was done at different times in an irregular sequence over the many years. However, they fit into a logical pattern which could be likened in a way to the periodic table of chemistry (Mendeleev). Because the face offered so many different structures, muscles and bones, it was a rich source of study.

Added to the past the junior author has contributed significantly to the present by including recent works with the presentation of issues dealing with stem cell, tissue regeneration and tissue engineering research. In addition, appropriately selected clinical work is included, a result of the further development and maturity of the specialties. And what does the future hold? No doubt unpredictable gigantic advances.

A logical sequence has been followed with an introduction, Part I. The Lower Face; Part II. The Midface; Part III. The Upper Face; Part IV. Tooth Development and Associated Structures; Part V. Cranial Sutures and Cranial Base; Part VI. Several reports (Chaps. 32-37) dealing with a 
synthesis and integrative interpretation of previous research as well as other selected subjects; Part VII. Public Health Aspects; APPENDIX dealing with becoming a Plastic Surgeon.

Full recognition and thanks are due to the important contributions of colleagues, students with their devoted expert secretarial skills (Catherine O’Hara, Misha Heller, Kristy Wasson, Rebekah Ashley, and Hurig Katchikian, untiring and totally dedicated) staff, and devoted families throughout the years. Especial recognition should be given to Michelle Van Vliet for her expert photography skills and cheerful countenance. Without their unfailing support this work would not have been possible.

We made every effort to minimize errors and inaccuracies. If any did occur, we apologize. And lastly, a great big thank you to both the publishers and editors. We owe a great debt of gratitude in particular and significant recognition to Sook-Cheng Lim, Scientific Editor of World Scientific Publishing and her staff for their patience, dedication, devotion, and meticulous attention to detail and guidance throughout the entire process of this work.

This volume is dedicated to the future leaders in the specialties of craniofacial biology and craniofacial surgery.

Thank you all.

Bernard G. Sarnat, M.D., D.D.S. James P. Bradley, M.D. 


\title{
Table of Contents
}

\author{
Craniofacial Biology and Craniofacial Surgery \\ Bernard G. Sarnat, M.D., D.D.S. and James P. Bradley, M.D.
}

Recognition $\quad \mathrm{v}$

Foreword by Geoffrey H. Sperber vii

Foreword by Joseph G. McCarthy xi

Preface $\quad \mathrm{xv}$

Chapter 1 Introduction 1

$\begin{array}{lll}\text { PART I THE LOWER FACE } & 15\end{array}$

$\begin{array}{lll}\text { Chapter } 2 \text { Growth Pattern of the Pig Mandible } & 17\end{array}$

Chapter 3 Mandibular Condylectomy in Young Monkeys 39

Chapter 4 Mandibular Condylectomy in Adult Monkeys 51

Chapter 5 Temporalis Muscle and Coronoid Process 69

$\begin{array}{lll}\text { Chapter } 6 & \text { Fractured Mandible and Incisor } & 73\end{array}$

Chapter 7 The Temporomandibular Joint 81

$\begin{array}{lll}\text { Chapter } 8 & \text { Condylar Tumors } & 97\end{array}$ 
xviii Craniofacial Biology and Craniofacial Surgery

Chapter 9 Overgrowth of Coronoid Processes 101

Chapter 10A Surgery of the Mandible: Some Clinical 105 and Experimental Considerations

Chapter 10B The Mandible: Clinical Considerations

PART II THE MIDFACE

Chapter 11 Osteology of the Rabbit Face

Chapter 12A Normal Growth of the Suture 155

Chapter 12B Rabbit Snout After Extirpation of the 165 Frontonasal Suture

Chapter 13 Growth Pattern of the Nasal Bone Region 177

$\begin{array}{lll}\text { Chapter } 14 \text { Rabbit Nasal Septum } & 189\end{array}$

Chapter 15 Growth of Multiple Facial Sutures 213

Chapter 16 Maxillary Sinus 225

Chapter 17 The Palate 235

Chapter 18 The Midface: Clinical Considerations 249

PART III THE ORBIT AND EYE 291

Chapter 19 Osteology of the Orbit 293

Chapter 20 Deceleration of Growth of the Orbit 297

Chapter 21 Orbital Volume After Increase of Orbital Contents 321

Chapter 22 The Eye 329

Chapter 23 The Upper Face and Orbit: Clinical Considerations 335

PART IV TOOTH DEVELOPMENT AND ASSOCIATED 355 CONDITIONS

Chapter 24 Tooth Development 357

Chapter 25 Effects of Hibernation on Tooth Development 361 
Chapter 26 Yellow Phosphorus and Teeth

Chapter 27 Anodontia

Chapter 28 Ameloblastoma

Chapter 29 Congenital Syphilis 387

Chapter 30 Enamel Hypoplasia 389

PART V THE CRANIUM

Chapter 31A The Skull Base, Sutures, and Long Bones

Chapter 31B Cranial Sutures: Clinical Considerations

\section{PART VI SOME LESSONS LEARNED}

Chapter 32 Differential Growth and Healing of Bones and Teeth

Chapter 33 Sutural Growth

Chapter 34 Effects and Noneffects of Personal Environmental Experimentation on Postnatal Craniofacial Growth

Chapter 35 Interstitial Growth of Bones

Chapter 36 Some Methods of Assessing Growth of Bones

Chapter 37 Cartilage and Cartilage Implants

\section{PART VII PUBLIC HEALTH ASPECTS}

Chapter 38A The Teeth as Recorders of Systemic Disease

Chapter 38B Rickets

Chapter 38C Congenital Syphilis

Chapter 38D Sickle Cell Anemia 
xx Craniofacial Biology and Craniofacial Surgery

Chapter 38E Oral and Facial Cancer 551

$\begin{array}{lll}\text { Chapter 38F Oral Occupational Disease } & 555\end{array}$

Appendix A Becoming a Plastic Surgeon - Yesterday (BGS) 557

Appendix B Becoming a Plastic Surgeon — Today (JPB) 575

$\begin{array}{ll}\text { Index } & 579\end{array}$ 